\title{
Morphometric study of Navicula morphospecies (Bacillariophyta) with respect to diatom life cycle
}

\author{
Jana Veseld ${ }^{1 *}$, Jiř́i Neustupa ${ }^{1}$, Martina PichrtovÁ ${ }^{1} \&$ Aloisie PoulíčKovÁ ${ }^{2}$ \\ ${ }^{1}$ Department of Botany, Faculty of Science, Charles University, Benátská 2, CZ-128 01 Prague 2, Czech Republic; \\ *Corresponding author e-mail: vesela6@natur.cuni.cz \\ ${ }^{2}$ Department of Botany, Faculty of Science, Palacký University, Svobody 26, CZ-771 46 Olomouc, Czech \\ Republic
}

\begin{abstract}
Quantitative and qualitative variation in valve morphology in strains of Navicula cryptocephala and $N$. trivialis were examined using conventional valve measurements (length, width, striae density) and landmarkbased geometric morphometric method. The ability of morphometric techniques to distinguish individual strains on the basis of postinitial and/or sexually competent cells was assessed by multivariate analyses and permutation tests. The data showed that each strain had unique valve characters, which were shared by both large postinitial and small sexually competent cells. Landmarks representing central area and apical ends of the valves were primarily the most useful for discrimination between strains. The geometric morphometric techniques appeared to be enough sensitive to distinguish subtle morphological differences between Navicula morphospecies clonal cultures withouth any interference of diatom life cycle stage.
\end{abstract}

Key words: canonical variate analysis, geometric morphometry, life cycle, Navicula cryptocephala, Navicula trivialis, sliding landmarks

\section{Introduction}

Taxonomy of diatoms has primarily been based on the morphology of diatom frustules observed in light microscope. Electron microscopy revealed other diverse valve structures, which have been used for description of new diatom species and genera (e.g., Round et al. 1990, VAN DE VIJVER 2002). However, molecular data demonstrated higher diatom species diversity than recognizable using traditional morphology (MANN et al. 2003, BehnKe et al. 2004, Amato et al. 2007, VANORMELINGEN et al. 2007). Many phenotypebased species were proved to be complexes of cryptic species, with almost identical morphology (PoulíčKová \& Mann 2006, Mann et al. 2008). However, quantitative morphometric analyses of valve outlines revealed the small-scale shape differences between individual micro-species (reviewed by MANN et al. 2004). Traditionally, the conventional morphometric measurements of length, width and other valve characters as e.g., striae or areolae density, qualitative description of raphe ends or central area, were used (e.g., Droop et al.2000, Siver \& BASKette2004, KnAPp etal.2006). Morphometrics underwent "scientific revolution" in 1990's (RohlF \& Marcus 1993, Adams et al. 2004) that resulted in what is now called geometric morphometrics (AdAMs et al. 2004, ZeLDITCH et al. 2004). Geometric morphometrics is based on analyses of configurations of homologous points (landmarks) or landmark-registered outlines (BoOKSTERIN 1997). In diatom research, geometric morphometric methods were recently used in taxonomic (Beszteri et al. 2005, FránKová et al. 2009), phylogenetic (EDgar \& THERIOT 2004) and ecological applications (PotAPOva \& HAMILTON 2007). One particular difference of the landmarkbased geometric morphometrics from traditional measurements relies in inherent separation of size differences from the landmarks data prior to the statistical analysis (data reflecting shape variation with size of the cells are standardized to a unit dimension). Thus, differences in size and shape of different populations or species can be analysed separately. However, the allometric shape dynamics caused by the size change related to vegetative diatom life cycle may still influence 
the shape of the investigated populations (MANN \& Chepurnov 2005). Therefore, in the present study, we analysed valve morphology of cells in particular, well-identified stages of their life cycle. We used the large postinitial and small sexually competent cells in eight strains of Navicula cryptocephala Kützing and $N$. trivialis LANGe-Bertalot using conventional and landmark-based morphometric approaches. Both cell types represented the size extremes of the usual variation of each strain within life cycle. We aimed to address the question whether the individual strains could be correctly identified at various stages of their life cycle using the morphometric data.

\section{Material and Methods}

Altogether eight monoclonal cultures of Navicula cryptocephala and N. trivialis isolated from Czech, Scottish and Australian lake epipelon were examined (Table 1). Isolation, cultivation and preparation of strains followed methods described previously by PoulíčKovÁ \& MANN (2006). Navicula species under study are homothalic ( $N$. cryptocephala) and automictic ( $N$. trivialis), thus both exhibit sexual reproduction within monoclonal cultures. Sexually competent /postinitial cells were obtained from monoclonal cultures under sexual reproduction, containing both cell types. Valves were cleaned in acids and mounted in Naphrax as descibed many times elsewhere (PoulíčKová \& ManN 2006).

Micrographs of approximately 30 postinitial and 30 sexually competent cells of each strain (a total of 464 valves) were obtained using a light microscope Zeiss Axioimager with a Zeiss Axiocam HRc digital camera (Carl Zeiss, Jena) capable of $1388 \times 1040$ pixel resolution. Images were captured and managed using Zeiss Axiovision Version 4.5 imaging software. Differential interference contrast (DIC) optics was used at $\times 100$ planapochromat lens, nominal numerical aperture 1.4.

In all frustules, length, width and striae density along the axial area immediately above the central area were recorded. Landmarks were placed along valve outline (36) and along the central area, at the raphe and striae endings (12). Of these 48 landmarks, 10 landmarks were in fixed positions (no. 1-4: intersections of a cell outline with apical and transapical axis; no. 37-42: the raphe central endings and ends of the longest striae in the central area; Fig. 1) and remaining landmarks were semilandmarks that were allowed to slide along the abscissa connecting adjacent landmarks (BooksteIN 1997). The TPS-series software (RoHLF 2007) was used for most geometric morphometric

Table 1. Characteristics of investigated Navicula cryptocephala (navcry) and N. trivialis (navtri) strains.

\begin{tabular}{|c|c|c|c|c|c|c|c|}
\hline Name & Locality & GPS & Species & Stage & $\begin{array}{c}\text { Length } \\
(\mu \mathrm{m})\end{array}$ & $\begin{array}{l}\text { Width } \\
(\mu \mathrm{m})\end{array}$ & $\begin{array}{c}\text { Stria density } \\
\left(10^{-1} \mu \mathrm{m}\right)\end{array}$ \\
\hline A & United Kingdom & $56^{\circ} 16^{\prime} 00^{\prime} \mathrm{N}$ & navcry & initial & $38.4-44.4$ & $7.2-8.0$ & $16-17$ \\
\hline $27 \mathrm{~L}$ & Loch Lubnaig & $4^{\circ} 17^{\prime} 10^{\prime} \mathrm{W}$ & & sexual & $24.6-26.5$ & $6.0-6.8$ & $16-17$ \\
\hline B & United Kingdom & $55^{\circ} 57^{\prime} 50^{\prime} \mathrm{N}$ & navcry & initial & $42.0-46.0$ & $6.9-7.8$ & $16-17$ \\
\hline $460 \mathrm{R}$ & RBG pond & $3^{\circ} 12^{\prime} 22^{\prime} \mathrm{W}$ & & sexual & $23.5-25.4$ & $5.3-6.8$ & $15-17$ \\
\hline $\mathrm{C}$ & Australia & $37^{\circ} 47^{\prime} 17^{\prime} \mathrm{S}$ & navcry & initial & $40.4-46.0$ & $7.6-8.5$ & $17-18$ \\
\hline $647 \mathrm{~K}$ & Kew Bilabong & $145^{\circ} 02^{\prime} 36^{\prime} \mathrm{E}$ & & sexual & $24.6-26.6$ & $6.2-7.0$ & $16-18$ \\
\hline $\mathrm{D}$ & Czech Republic & $49^{\circ} 17^{\prime} 58^{\prime} \mathrm{N}$ & navtri & initial & $49.9-56.2$ & $9.8-11.4$ & $13-14$ \\
\hline B145 & Bezedník & $17^{\circ} 43^{\prime} 35^{\prime} \mathrm{E}$ & & sexual & $29.5-35.5$ & $6.9-8.8$ & $13-15$ \\
\hline E & Czech Republic & $49^{\circ} 17^{\prime} 22^{\prime} \mathrm{N}$ & navtri & initial & $44.0-53.6$ & $9.1-11.0$ & $13-14$ \\
\hline HV5 & Horní Ves reservoir & $17^{\circ} 41^{\prime} 31^{\prime} \mathrm{E}$ & & sexual & $28.1-36.5$ & $7.4-8.6$ & $13-15$ \\
\hline $\mathrm{F}$ & Czech Republic & $49^{\circ} 43^{\prime} 39^{\prime} \mathrm{N}$ & navcry & initial & $37.7-40.1$ & $6.6-7.8$ & $16-17$ \\
\hline $\mathrm{O} / 26$ & Obectov & $16^{\circ} 55^{\prime} 43^{\prime} \mathrm{E}$ & & sexual & $23.1-25.4$ & $5.2-6.3$ & $16-17$ \\
\hline G & Czech Republic & $49^{\circ} 43^{\prime} 39^{\prime} \mathrm{N}$ & navtri & initial & $51.4-58.5$ & $10.5-12.4$ & $12-13$ \\
\hline $\mathrm{O} / 70$ & Obectov & $16^{\circ} 55^{\prime} 43^{\prime} \mathrm{E}$ & & sexual & $34.3-37.1$ & $8.2-9.1$ & $12-14$ \\
\hline $\mathrm{H}$ & Czech Republic & $49^{\circ} 43^{\prime} 39^{\prime} \mathrm{N}$ & navcry & initial & $39.4-42.7$ & $6.7-7.4$ & $16-17$ \\
\hline $\mathrm{O} / 71$ & Obectov & $16^{\circ} 55^{\prime} 43^{\prime} \mathrm{E}$ & & sexual & $24.4-26.7$ & $5.7-6.4$ & $15-17$ \\
\hline
\end{tabular}


analyses. The landmarks were digitized using TpsDig ver. 2.05. Valves were symmetrised along both the apical and transapical axes because valve symmetry (MANN 1983) could not always be determined from the micrographs focused primarily on the valve outline. Therefore, the asymmetric component of shape variation in valves was eliminated from data and subsequent analyses were conducted on symmetric configurations (KLINGENBERG et al. 2002). Following the general Procrustes superimposition, the thin-plate spline analysis based on tangent space projections was conducted (BooksteIn 1991; ZELDITCH et al. 2004). The mean configurations of individual strains were illustrated using the deformation grids based on the thin-plate spline interpolation (ZELDITCH et al. 2004).

The principal component analyses (PCA) of partial warps and the uniform component were separately conducted on three sets of objects: the postinitial cells, the sexually competent cells and the entire set of 464 cells. For these analyses, we used the TpsRelw ver 1.45. In all three sets, we used the scores of the objects on all the 15 non-zero PC axes for further analyses. Conventional measurements of the postinitial cells, sexual cells and the combined set were standardized before their use in statistical analyses. Geometric morphometric characters, conventional measurements and combined geometric and conventional morphometric data of the three datasets were used in the canonical variate analyses (CVA), two-group multivariate permutation tests on Mahalanobis distance (1000 permutations), and series of linear discrimination analyses assessing the percentage of correct classification of individual valves into their appropriate groups (strain) on the basis of the linear discriminant function. The geometric morphometric and conventional data were combined by normalization by the column-wise subtracting the mean and dividing by standard deviation (geometric morphometric data represented first $15 \mathrm{PC}$ axes of the entire set of 464 cells, conventional data represented measurements of individual cells). The discriminative power of individual valve areas was evaluated using the F-value of NPMANOVA (non-parametric MANOVA, Anderson 2001). The Procrustes-superimposed coordinates of individual landmarks were separately used in series of NPMANOVA tests in all three investigated sets (the postinitial cells, the sexually competent cells and the combined set). The F-value resulting from NPMANOVA, indicating the degree of separation between groups was used for evaluation of discriminative power of individual landmarks. Statistical analyses were performed using PAST ver. 1.85 (HAMmER et al. 2001).

\section{Results}

Differences in shape between postinitial and sexually competent cells were evident from the
PCA ordination plot of geometric morphometric data, relative warp analysis (Fig. 2). The ordination plot representing the first and second RW axes accounted for $95.7 \%$ of the total shape variability. Along the first axis (spanning 64.7\% of the variability), the postinitial cells were clearly separated from the sexually competent cells. Shape dynamics along this axis reflected the change from thin, elongated postinitial cells to more rounded sexual cells (Fig. 2). The second RW axis (31.0\% of the variation) did not discriminate between postinitial and sexual cells, but it reflected the shape change of the central part of the valves. Not surprisingly, ranges of width and length in postinitial and sexually competent cells within the strains did not overlap. In addition, Navicula trivialis strains (D, E, G) had larger cells than $N$. cryptocephala strains (Table 1, Fig. $3)$. The mean valve shapes of individual groups (postinitial cells, sexual cells and combined sets in all strains) within strains are visualised by thinplate splines as deformation from the overall mean configuration of landmarks (Fig. 4).

The separate canonical variates analyses (CVA) of geometric morphometric data (Fig. 5a), conventional measurements (Fig. 5b) and of the combined set of standardized geometric morphometric data and measurements (Fig. 5c) demonstrate shape and form separation of strains. Strain centroids clustered differently in the ordination plots produced from different morphometric data sets. However, three $N$. trivialis strains (D, E, G) were in each CVA diagram separated from $N$. cryptocephala strains (Fig. 5). The degree of separation (evaluated by Mahalanobis distance) and the percentage of

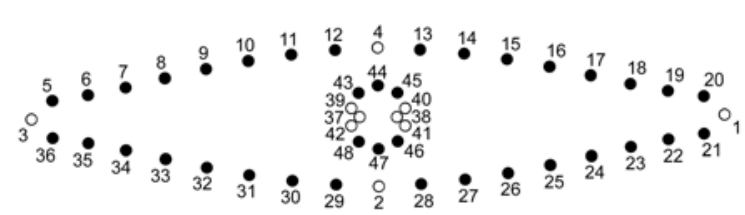

Fig.1. Positions of landmarks. Fixed landmarks are represented by the empty circles and semilandmarks by the filled circles.

Fig. 2: Relative warp analysis (RWA). Postinitial cells are represented by crosses and sexually competent cells by circles. Shape changes along the first $(64.7 \%)$ and second (31.0\%) RW axes are demonstrated.

Fig. 3: Scatter plot of length versus width of Navicula strains. For clones (A-H) see Table 1, small letters indicate sexually competent cells (s) or postinitial cells (i). 

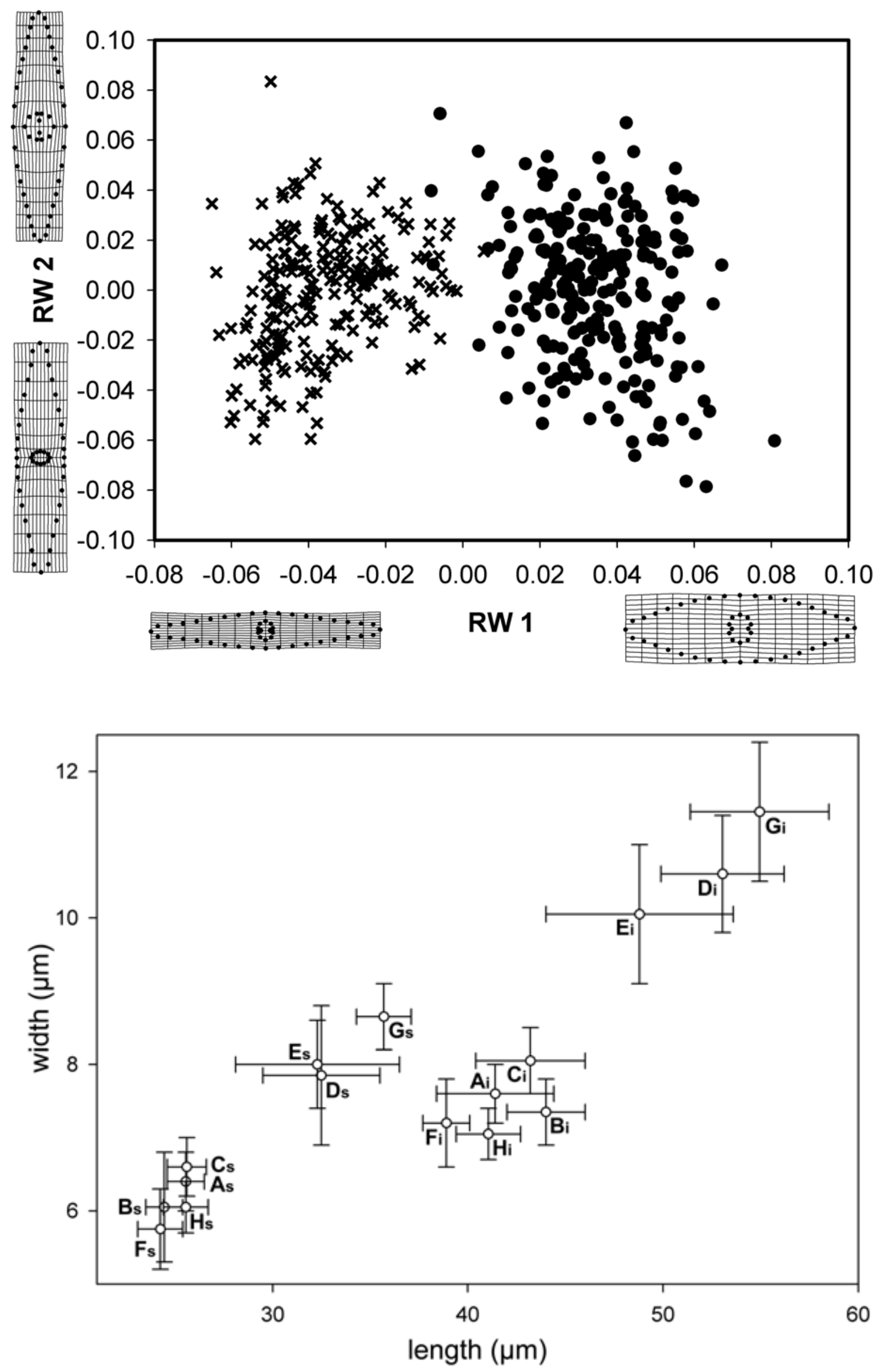
a
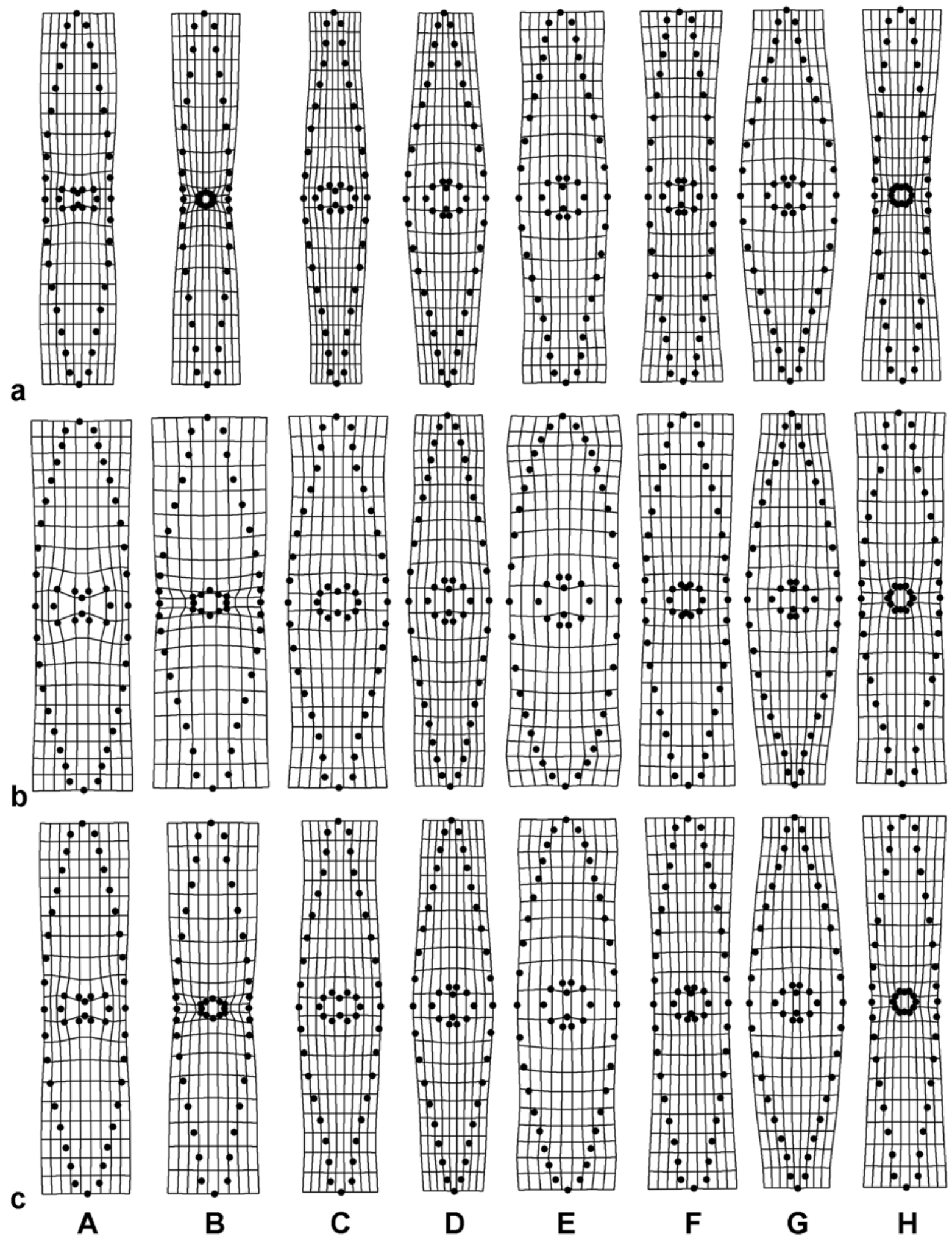
C

Fig. 4: Reconstruction of characteristic shape of strains by the deformation of thin-plate spline from mean configuration: (a) postinitial cells; (b) sexually competent cells; (c) postinitial + sexual cells. For clones (A-H) see Table 1. 

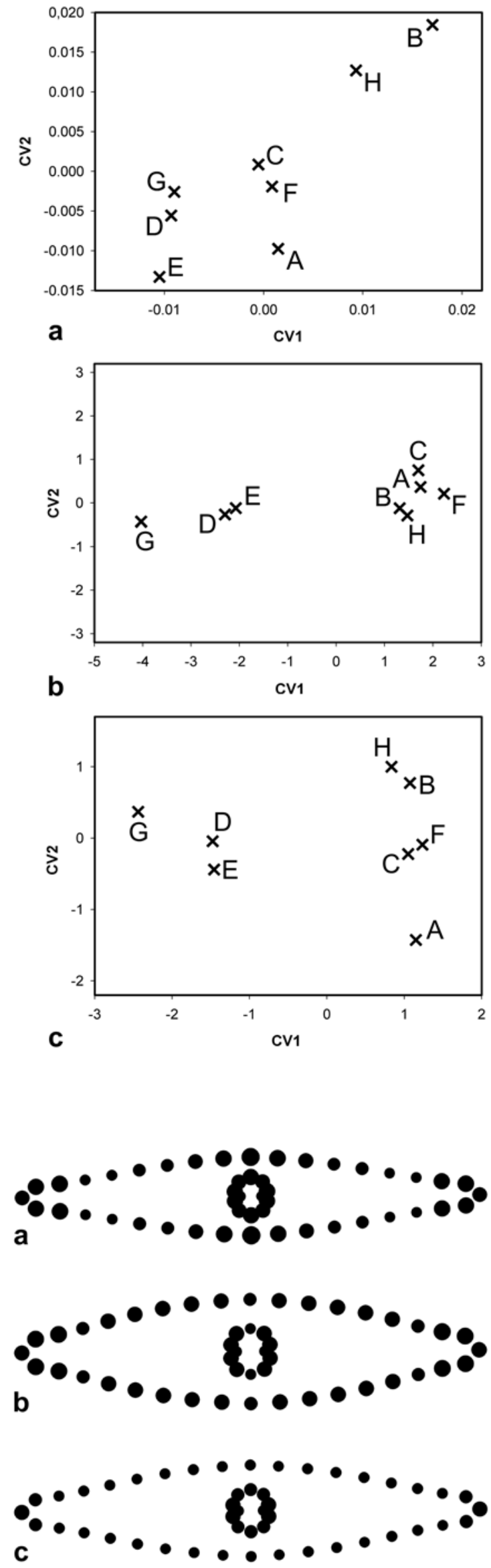

correct discrimination between strains differed among different data sets (postinitial and/or sexual cells, geometric and/or conventional morphometrics; Tables 2a, 2b). The shape differentiation of strains was very high in sets of exclusively postinitial or sexually competent cells. When using the geometric morphometric data, there was an average $98.3 \%$ correct strain assignment for postinitial cells and $98.4 \%$ for sexual cells. As for the traditional measurements, the average correct strain assignment was $98.6 \%$ for postinitial cells and $95.4 \%$ for sexual cells. In the combined set of both postinitial and sexually competent cells, discrimination values between strains were slightly lower. There was average correct discrimination of $95.0 \%$ cells in geometric morphometric data and 93.9\% in measurements. The combined standardized geometric morphometric and measurements data in average correctly discriminated $97.9 \%$ of cells in two-group tests.

The apical parts of cells and the central areas were clearly the most strain-specific in postinitial cells (Fig. 6a) Characteristic shape features of strains were more regularly distributed along the cell outline in sexually competent cells (Fig. 6b). In the combined set, shape of central area was the most important valve feature for discrimination between strains (Fig. 6c).

\section{Discussion}

Species concept in diatoms has often been too wide and that there are many more species than are currently recognized, even in areas of the world that are comparatively well known, such as Europe (MANN 1999, MANN et al. 2004). The modern morphometric techniques appeared to be sensitive tool for distinguishing subtle morphological differences between morphotypes of diatom strains traditionally assigned to a single species (Rhode et al. 2001, Pappas \& Stoermer

Fig. 5: Centroids of strains calculated from canonical variates analysis (CVA) using: a) geometric morphometric data, b) conventional morphometric data, c) geometric + conventional morphometric data. For clones (A-H) see Table 1.

Fig. 6: The importance of landmarks for discrimination between strains. Sizes of landmarks correspond to amount of dissimilarity between strains within postinitial cells (a), sexually competent cells (b), and both together (c). 
Table 2a. Geometric morphometric data. Matrices of pairwise comparisons (Mahalanobis distance) between strains $=$ first line and percentage of correctly classified cells (discriminant analysis) = second line. Right triangle: postinitial / sexual cells. Left triangle: postinitial + sexually competent cells including within-strain variation (differences between postinitial and sexual cells) / postinitial + sexual cells without within-strain variation (removed by multiple regression). Average percentages of correctly classified cells are in bold. Significance of NPMANOVA tests: $\mathrm{p}<0.001$, value in italics $\mathrm{p}<0.01$.

\begin{tabular}{ccccccccc}
\hline & $\mathbf{A}$ & $\mathbf{B}$ & $\mathbf{C}$ & $\mathbf{D}$ & $\mathbf{E}$ & $\mathbf{F}$ & $\mathbf{G}$ & $\mathbf{H}$ \\
\hline \multirow{2}{*}{$\mathrm{A}$} & $98.3 / 98.4$ & $0.76 / 0.67$ & $0.52 / 0.62$ & $0.76 / 0.79$ & $1.03 / 0.83$ & $0.55 / 0.52$ & $0.83 / 1.09$ & $0.60 / 0.85$ \\
& & $100 / 100$ & $96.3 / 98.3$ & $98.2 / 100$ & $100 / 100$ & $96.4 / 96.6$ & $100 / 100$ & $100 / 100$ \\
$\mathrm{~B}$ & $0.40 / 0.41$ & & $0.76 / 0.38$ & $0.91 / 0.72$ & $1.29 / 0.75$ & $0.73 / 0.44$ & $1.02 / 0.98$ & $0.33 / 0.55$ \\
& $99.1 / 98.3$ & & $100 / 94.9$ & $100 / 100$ & $100 / 100$ & $100 / 94.9$ & $100 / 100$ & $90 / 98.3$ \\
& $0.36 / 0.39$ & $0.26 / 0.28$ & & $0.60 / 0.80$ & $0.57 / 0.88$ & $0.60 / 0.50$ & $0.60 / 1.02$ & $0.92 / 0.45$ \\
& $99.1 / 98.2$ & $92.2 / 97.4$ & & $98.3 / 100$ & $100 / 100$ & $98.3 / 98.3$ & $98.2 / 100$ & $100 / 96.6$ \\
& $0.49 / 0.48$ & $0.45 / 0.47$ & $0.33 / 0.32$ & & $0.43 / 0.50$ & $0.65 / 0.60$ & $0.44 / 0.52$ & $0.60 / 0.48$ \\
D & $100 / 100$ & $99.2 / 100$ & $96.6 / 98.3$ & & $96.6 / 96.7$ & $98.3 / 100$ & $94.8 / 94.8$ & $100 / 98.3$ \\
& $0.49 / 0.48$ & $0.50 / 0.50$ & $0.33 / 0.33$ & $0.17 / 0.17$ & & $0.65 / 0.71$ & $0.35 / 0.68$ & $0.83 / 0.69$ \\
E & $100 / 100$ & $100 / 100$ & $96.5 / 96.6$ & $82.2 / 85.6$ & & $100 / 100$ & $91.1 / 98.3$ & $100 / 98.3$ \\
& $0.30 / 0.31$ & $0.27 / 0.27$ & $0.32 / 0.33$ & $0.33 / 0.35$ & $0.38 / 0.37$ & & $0.62 / 0.87$ & $0.63 / 0.35$ \\
F & $93.0 / 96.5$ & $94.1 / 95.0$ & $95.7 / 95.7$ & $96.6 / 99.2$ & $97.4 / 98.3$ & & $96.5 / 100$ & $100 / 91.4$ \\
& $0.54 / 0.53$ & $0.46 / 0.47$ & $0.30 / 0.30$ & $0.21 / 0.22$ & $0.27 / 0.31$ & $0.40 / 0.43$ & & $0.79 / 0.63$ \\
G & $100 / 100$ & $100 / 100$ & $92.0 / 95.6$ & $88.8 / 86.2$ & $93.9 / 93.9$ & $97.4 / 98.3$ & & $100 / 100$
\end{tabular}

2003; MANN et al. 2004). In this study, we were able to characterize and distinguish quantitatively and qualitatively all of the investigated clones of Navicula cryptocephala and N. trivialis by means of conventional and geometric morphometric methods. The data obtained from morphometric analyses of postinitial and sexually competent cells showed that each strain of $N$. cryptocephala and $N$. trivialis had unique valve characters shared by both stages of the life cycle. Shape of the central area and apical ends of valves were particularly the most useful parts of the valve. In accordance, the importance of central area for identification of naviculoid diatoms was suggested in other studies (e.g., BARBer \& HaWorth 1981, Round 2001). The traditional measurements reflected mostly differences in size of the valves and were much less successful in discrimination of strains in data set including postinitial and sexually competent cells, where most of the size variation was within, rather than between the strains. On the other hand, the geometric morphometric data (discriminating the postinitial and/or the sexual cells between pairs of strains solely on the basis of shape differences and the quantitative shape properties spanned by the geometric morphometric descriptors) were quite powerful even in these sets with cells taken from the opposite stages of the diatom life cycle combined into single group in each strain. Shape differences were distinctly less dependent on the life cycle stage and the geometric morphometric data included strong strain-specific signal in most pair comparisons. However, the average correct assignment of individual cells still increased in discrimination analyses of strain pairs using the normalized geometric morphometric and traditional data. Phenotypic variation may be influenced by several factors, including growth at different environmental conditions, changes during life cycle stage, and genetic differentiation. Although morphological and physiological variation has been observed in different protists under influence of temperature (MonTAgnes \& Daniel 2001, Gächter \& Weisse 2006, Neustupa et al. 2008), pH (WeISSE et al. 2007) and salinity (Clavero et al. 2000, Finlay et al. 2006), a few such studies were done in diatoms (Schultz 1971, Schmid 1976, Cox 1994). Changes in valve shapes 
Table $2 b$. Conventional morphometric data. Matrices of pairwise comparisons (Mahalanobis distance) between strains $=$ first line and percentage of correctly classified cells (discriminant analysis) = second line. Right triangle: postinitial / sexual cells. Left triangle: postinitial + sexually competent cells / postinitial + sexual cells, combined conventional measurements with geometric morphometric data. Average percentages of correctly classified cells are in bold. Significance of NPMANOVA tests: $\mathrm{p}<0.001$.

\begin{tabular}{ccccccccc}
\hline & $\mathbf{A}$ & $\mathbf{B}$ & $\mathbf{C}$ & $\mathbf{D}$ & $\mathbf{E}$ & $\mathbf{F}$ & $\mathbf{G}$ & $\mathbf{H}$ \\
\hline \multirow{2}{*}{$\mathrm{A}$} & $98.6 / 95.4$ & $1.26 / 0.67$ & $0.28 / 0.20$ & $2.60 / 2.47$ & $2.59 / 2.52$ & $0.27 / 0.69$ & $3.62 / 5.11$ & $0.75 / 0.55$ \\
& & $100 / 98.3$ & $83.3 / 86.4$ & $100 / 100$ & $100 / 100$ & $87.3 / 98.4$ & $100 / 100$ & $100 / 100$ \\
$\mathrm{~B}$ & $0.11 / 0.44$ & & $1.41 / 1.33$ & $2.43 / 2.56$ & $3.06 / 2.15$ & $1.91 / 0.68$ & $3.73 / 5.19$ & $1.28 / 0.91$ \\
& $68.1 / 99.1$ & & $100 / 94.9$ & $100 / 100$ & $100 / 100$ & $100 / 98.4$ & $100 / 100$ & $100 / 98.3$ \\
$\mathrm{C}$ & $0.15 / 0.40$ & $0.20 / 0.35$ & & $2.67 / 2.69$ & $2.82 / 2.82$ & $0.86 / 0.75$ & $3.90 / 4.84$ & $0.71 / 1.41$ \\
& $77.0 / 99.1$ & $87.9 / 95.7$ & & $100 / 100$ & $100 / 100$ & $98.3 / 98.4$ & $100 / 100$ & $100 / 100$ \\
$\mathrm{D}$ & $0.70 / 0.96$ & $0.55 / 0.84$ & $0.70 / 0.95$ & & $0.37 / 0.75$ & $3.06 / 1.81$ & $1.02 / 1.48$ & $2.75 / 2.72$ \\
& $100 / 100$ & $100 / 100$ & $100 / 100$ & & $91.2 / 96.7$ & $100 / 100$ & $100 / 100$ & $100 / 100$ \\
& $0.95 / 1.04$ & $0.68 / 0.87$ & $0.94 / 1.02$ & $0.18 / 0.26$ & & $2.69 / 2.66$ & $1.13 / 1.40$ & $2.94 / 3.19$ \\
$\mathrm{E}$ & $100 / 100$ & $100 / 100$ & $100 / 100$ & $82.9 / 93.2$ & & $100 / 100$ & $100 / 100$ & $100 / 100$ \\
& $0.20 / 0.36$ & $0.17 / 0.40$ & $0.29 / 0.48$ & $0.98 / 1.17$ & $1.42 / 1.17$ & & $3.87 / 5.05$ & $1.33 / 0.80$ \\
$\mathrm{~F}$ & $86.3 / 97.4$ & $81.0 / 99.1$ & $93.2 / 100$ & $100 / 100$ & $100 / 100$ & & $100 / 100$ & $100 / 100$ \\
& $1.13 / 0.84$ & $0.91 / 0.86$ & $1.10 / 0.82$ & $0.68 / 0.37$ & $0.45 / 0.33$ & $1.52 / 0.91$ & & $3.86 / 5.29$ \\
$\mathrm{G}$ & $100 / 98.2$ & $100 / 100$ & $100 / 99.1$ & $100 / 97.4$ & $99.1 / 96.5$ & $100 / 98.3$ & & $100 / 100$ \\
& $0.27 / 0.46$ & $0.11 / 0.18$ & $0.44 / 0.49$ & $0.70 / 0.60$ & $0.99 / 0.84$ & $0.18 / 0.28$ & $1.15 / 0.60$ & $93.9 / 97.9$ \\
\hline
\end{tabular}

during ontogeny are discussed, e.g., by PAPPAS \& Stoermer (2003) and Mann \& Chepurnov (2005). The separation of both species $N$. cryptocephala and $N$. trivialis was expected, however, geometric morphometrics clearly separated also 3 clones of $N$. cryptocephala (A, C, F) from two others (B, H). N. cryptocephala populations have been previously found to be polymorphic with respect to cytological characteristics and reproduction (Geitler 1952, 1958, PoulíčKOvÁ $\&$ MANN 2006). The latter authors hypothesized the existence of pseudocryptic diversity within $N$. cryptocephala, which can be supported by our morphometric analysis. Nevertheless, to what extent the observed morphometric patterns reflected the microevolutionary differentiation of strains remains to be confirmed by the molecular methods.

\section{Acknowledgements}

We are grateful to Prof. D.G. Mann and Dr. K. Evans for sharing some Navicula clones, expertise and inspirative discussions. This work was supported by the Czech Science Foundation project no. 206/07/0115 and no. 206/08/0389, the research project of the Czech Ministry of Education no. 0021620828, and the Charles University Science Foundation project B-Bio 30108.

\section{References}

Adams, D.C., Rohlf, F.J. \& Slice, D.E. (2004): Geometric morphometrics: ten years of progress following the 'revolution'. - Italian Journal of Zoology 71: 5-16.

Amato, A., Kooistra, W.H.C.F., Ghiron, L.J.H., Mann, D.G., Pröschold, T. \& Montresor, M. (2007): Reproductive isolation among sympatric cryptic species in marine diatoms. - Protist 158: 193207.

Anderson, M.J. (2001): A new method for nonparametric multivariate analysis of variance. Austral Ecology 26: 32-46.

Barber, H.G. \& Haworth, E.Y (1981): A guide to the morphology of the diatom frustule with a key to the British freshwater genera. - 112 pp., Freshwater Biological Association.

Behnke, A., Friedl, T., Chepurnov, V.A. \& Mann, D.G. (2004): Reproductive compatibility and rDNA 
sequence analyses in the Sellaphora pupula species complex (Bacillariophyta). - Journal of Phycology 40: 193-208.

Beszteri, B., Ács, E. \& Medlin, L. (2005): Conventional and geometric morphometric studies of valve ultrastructural variation in two closely related Cyclotella species (Bacillariophyta). - European Journal of Phycology 40: 89-103.

Bookstein, F.L. (1991): Morphometric tools for landmark data: geometry and biology. - 435 pp., Cambridge University Press, Cambridge.

Bookstein, F.L. (1997): Landmark methods for forms without landmarks: morphometrics of group differences in outline shape. - Medical Image Analysis 1: 225-243.

Clavero, E., Hernández-Mariné, M., Grimalt, J.O. \& Garcia-Pichel, F. (2000): Salinity tolerance of diatoms from Thalassic hypersaline environments. - Journal of Phycology 36: 1021-1034.

Cox, E.J. (1994): Morphological variation in widely distributed diatom taxa: taxonomic and ecological implications. - In: MARIANO, D. \& Montresor, M. (eds): Proceedings $13^{\text {th }}$ International Diatom Symposium. - pp. 335345, Biopress Ltd., Bristol.

Droop, S.J.M. (1994): Morphological variation in Diploneis smithii and D. fusca (Bacillariophyceae). - Archiv fuer Protistenkunde 144: 249-270.

Droop, S.J.M., ManN, D.G. \& LoKhorst, G.M. (2000): Spatial and temporal stability of demes in Diploneis smithii / D. fusca (Bacillariophyta) supports a narrow species concept. - Phycologia 39: 527-546.

Edgar, S.M. \& Theriot, E.C. (2004): Phylogeny of Aulacoseira (Bacillariophyta) based on molecules and morphology. - Journal of Phycology 40: 772-788.

Finlay, B.J., Estebana, G.F., Brown, S., Fenchel, T., \& HoEF-EMden, K. (2006): Multiple cosmopolitan ecotypes within a microbial eukaryote morphospecies. - Protist 157: 377-390.

Fránková, M., PoulíčKová, A., Neustupa, J., Pichrtová, M. \& Marvan, P. (2009): Geometric morphometrics - a sensitive method for diatom morphospecies distinguishing: a case study on the sympatric populations of Reimeria sinuata and Gomphonema tergestinum (Bacillariophyceae) from the River Bečva, Czech Republic. - Nova Hedwigia 88: 81-95.

GÄChter, E. \& Weisse, T. (2006): Local adaptation among geographically distant clones of the cosmopolitan freshwater ciliate Meseres corlissi. I. Temperature response. - Aquatic Microbial Ecology 45: 291-300.

GeitLer, L. (1952): Untersuchungen über Kopulation und Auxosporenbildung pennater Diatomeen
IV. V. IV. Vierkernige Zygoten bei Navicula cryptocephala var. veneta fa. V. Allogamie bei Synedra rumpens var. fragilarioides. Österreichische Botanische Zeitschrift 99: 598-605.

Geitler, L. (1958). Notizen über Rassenbildung, Fortpflanzung, Formwechsel und morphologische Eigentümlichkeiten bei pennaten Diatomeen. - Österreichische Botanische Zeitschrift 105: 408-42.

Hammer, Ø., Harper, D.A.T. \& Ryan, P.D. (2001). PAST: Paleontological Statistics Software Package for Education and Data Analysis. Palaeontologia Electronica 4: 1-9.

Klingenberg, C.P., Barluenga, M. \& Meyer, A. (2002): Shape analysis of symmetric structures: quantifying variation among individuals and asymmetry. - Evolution 56: 1909-1920.

Knapp, J.M., Furey, P.C. \& Lowe, R.L. (2006): A comparison of the morphology and ultrastructure of the diatoms (Bacillariophyceae) Discostella stelligera and D. elentarii from two lakes in Fiordland, New Zealand. - New Zealand Journal of Marine and Freshwater Research 40: 429-438.

Mann, D.G. (1983): Symmetry and cell division in raphid diatoms. - Annals of Botany 52: 573581.

MAnN, D.G. (1999): The species concept in diatoms. Phycologia 38: 437-495.

ManN, D.G. \& Chepurnov, V.A. (2005): Auxosporulation, mating system, and reproductive isolation in Neidium (Bacillariophyta). - Phycologia 44: 335-350.

Mann, D.G., Chepurnov, V.A. \& IdeI, M. (2003): Mating system, sexual reproduction, and auxosporulation in the anomalous raphid diatom Eunotia (Bacillariophyta). - Journal of Phycology 39: 1067-1084.

Mann, D.G., McDonald, S.M., Bayer, M.M., Droop, S.J.M., Chepurnov, V.A., Loke, R.E., Ciobanu, A. \& DU Buf, J.M.H. (2004): The Sellaphora pupula species complex (Bacillariophyceae): morphometric analysis, ultrastructure and mating data provide evidence for five new species. - Phycologia 43: 459-482.

Mann, D.G., Thomas, S.J. \& Evans, K.M. (2008): Revision of the diatom genus Sellaphora: a first account of the larger species in the British Isles. - Fottea 8: 15-78.

Montagnes, D.J.S. \& Franklin, D.J. (2001): Effect of temperature on diatom volume, growth rate, and carbon and nitrogen content: Reconsidering some paradigms. - Limnology and Oceanography 46: 2008-2018.

Neustupa, J., ŠŤastný, J. \& Hodač, L. (2008): Temperature-related phenotypic plasticity in the green microalga Micrasterias rotata. - Aquatic 
microbial ecology 51: 77-86.

Pappas, J.L. \& Stoermer, E.F. (2003): Legendre shape descriptors and shape group determination of specimens in the Cymbella cistula species complex. - Phycologia 42: 90-97.

Potapova, M. \& Hamilton, P.B. (2007): Morphological and ecological variation within the Achnanthidium minutissimum (Bacillariophyceae) species complex. - Journal of Phycology 43: 561-575.

PoulíčKovÁ, A. \& Mann, D.G. (2006): Sexual reproduction in Navicula cryptocephala (Bacillariophycae). - Journal of Phycology 42: 872-866.

Rhode, K.M.; Pappas, J.L. \& Stoermer E.F. (2001): Quantitative analysis of shape variation in type and modern populations of Meridion (Bacillariophyceae). - Journal of Phycology 37: 175-183.

RohLF, F.J. \& Marcus, L.S. (1993): A revolution in morphometrics. - Trends in ecology and evolution 8: 129-132.

RoнLF, F.J. (2007): TPS Series - Department of Ecology and Evolution, State University New York at Stony Brook, New York.

Round, F.E. (2001): Morphology of Navicula sensu stricto - an ecologist's perspective. - In: J $\mathrm{AHN}$, R., Kociolek, J.P., Witkowski, A. \& Compère, P. (eds): Lange-Bertalot Festschrift. - pp. 317326, Gantner, Ruggell.

Round, F.E., Crawford, R.M. \& Mann, D.G. (1990): The Diatoms: Biology and Morphology of the Genera. -747 pp., Cambridge University Press, Cambridge.

Schmid, A.M. (1976): Morphologische und physiologische Untersuchungen an Diatomeen des NeusiedlerSees: II. Licht- und resterelektronenmikroskopischeSchalenanalyse der Umweltabhängigen zyklomorphose von Anomoeoneis sphaerophora (Kg.)Pfitzer. Nova Hedwigia 28: 309-351.
Schultz, M.E. (1971): Salinity-related polymorphism in the brackish-water diatom Cyclotella cryptica. - Canadian Journal of Botany 49: 1285-1289.

Siver, P.A. \& Baskette, G. (2004): A morphological examination of Frustulia (Bacillariophyceae) from the Ocala National Forest, Florida, USA. - Canadian Journal of Botany 82: 629-644.

Van de Vijver, B., Frenot, Y. \& Beyens, L. (2002): Freshwater Diatoms from Ile de la Possession (Crozet Archipelago, Subantarctica). Bibliotheca Diatomologica 46: 1-412. J. Cramer, Berlin-Stuttgart.

Vanormelingen, P., Chepurnov, V.A., Mann, D.G., Cousin, S. \& Vyverman, W. (2007): Congruence of morphological, reproductive and ITS rDNA sequence data in some Australasian Eunotia bilunaris (Bacillariophyta). - European Journal of Phycology 42: 61-79.

VAnormelingen, P. Chepurnov, V.A., Mann, D.G., Sabbe, K. \& Vyverman, W. (2008): Genetic divergence and reproductive barriers among morphologically heterogeneous sympatric clones of Eunotia bilunaris sensu lato (Bacillariophyta). - Protist 159: 73-90.

Weisse, T., Scheffel, U., Stadler, P. \& Foissner, W. (2007): Local adaptation among geographically distant clones of the cosmopolitan freshwater ciliate Meseres corlissi. II. Response to $\mathrm{pH}$. Aquatic microbial ecology 47: 289-297.

Zelditch M.L., Swiderski D.L., Sheets D.H. \& FinK W.L. (2004): Geometric morphometrics for biologists: a primer. -452 pp., Elsevier Academic Press, London.

(C) Czech Phycological Society

Received April 20, 2009

Accepted May 21, 2009 